\title{
Clostridium difficile after haemolytic uraemic syndrome
}

\author{
D P Burgner, H Rfidah, T J Beattie, D V Seal
}

\begin{abstract}
Six children are described who developed diarrhoea associated with Clostridium difficile during the course of haemolytic uraemic syndrome. The significance of this infection is discussed within the context of the pathophysiology of haemolytic uraemic syndrome.

(Arch Dis Child 1993; 69: 239-240)
\end{abstract}

Haemolytic uraemic syndrome is the commonest cause of acute renal failure in British children. ${ }^{1}$ It is characterised by the triad of oliguric or anuric renal failure, thrombocytopenia, and microangiopathic haemolytic anaemia. The majority of children have a prodrome of bloody diarrhoea, although about $10 \%$ have no initial gastrointestinal symptoms. Cases may occur in isolation or in small outbreaks. ${ }^{2}$ Various microbial agents have been implicated in the pathogenesis of haemolytic uraemic syndrome: most importantly the verocytotoxin-producing Escherichia coli (subtype O157), ${ }^{1}$ but also Shigella sp, Campylobacter jejuni, Streptococcus pneumoniae, Yersinia pseudotuberculosis, and Salmonella sp. ${ }^{3}$

The gastrointestinal complications of haemolytic uraemic syndrome are well recognised and include colonic oedema and ischaemia, colonic perforation, and gastrointestinal haemorrhage. ${ }^{4}$

Pseudomembranous colitis has recently been described in two cases of haemolytic uraemic syndrome, with Clostridium difficile being isolated from the stool of one of these. ${ }^{5}$

We report six children who had haemolytic uraemic syndrome secondary to $E$ coli $\mathrm{O} 157$ and who subsequently developed diarrhoea associated with $C$ difficile. The characteristics of these patients are shown in the table.

\section{Case reports}

All children had evidence of $E$ coli 0157 infection from stool culture and/or from serological investigation. Evidence of $C$ difficile infection was not sought from the initial stool culture as all children had clinically obvious haemolytic uraemic syndrome.

Five of the six children had received antibiotics before the development of diarrhoea associated with $C$ difficile, in three antibiotics were given intraperitoneally on clinical suspicion of peritonitis that was not subsequently proved microbiologically. Two children received intravenous cefotaxime: one for seven days and the other for one day.

In all children the prodromal diarrhoea of the haemolytic uraemic syndrome had ceased at least four days before the development of diarrhoea associated with $C$ difficile. All had $C$ difficile isolated on stool culture and all had $C$ difficile cytotoxin $\mathrm{B}$ identified by enzyme linked immunosorbent assay (ELISA). No other faecal pathogens were identified and there was no microbiological evidence of continuing $E$ coli $\mathrm{O} 157$ infection. Two children had additional symptoms of abdominal pain

\begin{tabular}{|c|c|c|c|c|c|c|c|c|c|c|c|}
\hline $\begin{array}{l}\text { Case } \\
\text { No }\end{array}$ & $\operatorname{sex}$ & $\begin{array}{l}\text { Age at } \\
\text { onset } \\
\text { (years) }\end{array}$ & $\begin{array}{l}\text { Prodromal } \\
\text { symptoms } \\
\text { (duration) }\end{array}$ & $\begin{array}{l}\text { E Coli } 0157 \\
\text { infection } \\
\text { proved }\end{array}$ & $\begin{array}{l}\text { Maximum } \\
\text { plasma } \\
\text { creatinine } \\
\text { (رmoll) }\end{array}$ & $\begin{array}{l}\text { Dialysis } \\
\text { performed }\end{array}$ & $\begin{array}{l}\text { Antibiotic } \\
\text { treatment } \\
\text { (duration) }\end{array}$ & $\begin{array}{l}\text { Recurrent } \\
\text { gastro- } \\
\text { intestinal } \\
\text { symptoms }\end{array}$ & $\begin{array}{l}\text { Time of onset } \\
\text { of recurrent } \\
\text { symptoms } \\
\text { (days after } \\
\text { cessation } \\
\text { of prodromal } \\
\text { diarrhoea) } \\
\text { (days) }\end{array}$ & $\begin{array}{l}\text { Treatment } \\
\text { of } \\
\text { C difficile } \\
\text { infection }\end{array}$ & $\begin{array}{l}\text { Outcome } \\
\text { at follow } \\
\text { up }\end{array}$ \\
\hline 1 & $\mathbf{F}$ & $7 \cdot 5$ & $\begin{array}{l}\text { Bloody } \\
\text { diarrhoea } \\
\text { (7 days) }\end{array}$ & $\begin{array}{l}\text { Yes (stool } \\
\text { culture and } \\
\text { serology }\end{array}$ & 190 & $\begin{array}{l}\text { Yes } \\
\quad \text { (peritoneal) }\end{array}$ & $\begin{array}{l}\text { Netilmicin, } \\
\text { vancomycin } \\
\text { (IP } 6 \text { days) }\end{array}$ & $\begin{array}{l}\text { Vomiting, } \\
\text { diarrhoea }\end{array}$ & 10 & $\begin{array}{l}\text { Oral } \\
\quad \text { vancomycin }\end{array}$ & $\begin{array}{l}\text { Symptom } \\
\text { free }\end{array}$ \\
\hline 2 & $\mathbf{F}$ & 2 & $\begin{array}{r}\text { Diarrhoea } \\
\text { (17 days) }\end{array}$ & $\begin{array}{l}\text { Yes } \\
\quad \text { (serology) }\end{array}$ & 658 & $\begin{array}{l}\text { Yes } \\
\quad \text { (peritoneal) }\end{array}$ & $\begin{array}{l}\text { Ceftazidime, } \\
\text { tobramycin } \\
\text { (IV } 4 \text { days); } \\
\text { ceftazidime, } \\
\text { netilmicin } \\
\text { (IP } 4 \text { days) }\end{array}$ & Diarrhoea & 11 & $\begin{array}{l}\text { Oral } \\
\text { vancomycin }\end{array}$ & $\begin{array}{l}\text { Symptom } \\
\text { free }\end{array}$ \\
\hline 3 & $\mathbf{M}$ & 2 & $\begin{array}{l}\text { Bloody } \\
\text { diarrhoea } \\
\text { (5 days) }\end{array}$ & $\begin{array}{l}\text { Yes } \\
\quad \text { (serology) }\end{array}$ & 500 & $\begin{array}{l}\text { Yes } \\
\text { (peritoneal) }\end{array}$ & $\begin{array}{c}\text { Cefotaxime } \\
\text { (IV } 1 \text { day) }\end{array}$ & Diarrhoea & 6 & $\begin{array}{l}\text { Oral } \\
\text { vancomycin }\end{array}$ & $\begin{array}{c}\text { Symptom } \\
\text { free }\end{array}$ \\
\hline 4 & $\mathbf{F}$ & 4 & $\begin{array}{l}\text { Bloody } \\
\text { diarrhoea } \\
\text { (24 days) }\end{array}$ & $\begin{array}{l}\text { Yes } \\
\quad \text { (serology) }\end{array}$ & 88 & No & Nil & $\begin{array}{l}\text { Diarrhoea, } \\
\text { abdominal } \\
\text { pain }\end{array}$ & 4 & Nil & $\begin{array}{l}\text { Symptom } \\
\text { free }\end{array}$ \\
\hline 6 & $\mathbf{F}$ & 13 & $\begin{array}{l}\text { Bloody } \\
\text { diarrhoea } \\
\text { (7 days) }\end{array}$ & $\begin{array}{l}\text { Yes } \\
\quad \text { (serology) }\end{array}$ & 675 & $\begin{array}{l}\text { Yes } \\
\quad \text { (peritoneal) }\end{array}$ & $\begin{array}{l}\text { Netilmicin, } \\
\text { vancomycin } \\
\text { (IP 14 days) }\end{array}$ & Diarrhoea & 20 & Nil & $\begin{array}{c}\text { Symptom } \\
\text { free }\end{array}$ \\
\hline
\end{tabular}


and vomiting and one had the typical malodorous stool of pseudomembranous colitis. Four children were sufficiently unwell to require treatment with oral vancomycin. The diarrhoea in two children was self limiting over a five day period and the symptoms had resolved by the time the $C$ difficile toxin was identified. Treatment was therefore not given.

Although four cases overlapped during their inpatient stay, each child had been barrier nursed in separate cubicles. Moreover patients numbers 1, 3, and 6 developed diarrhoea associated with $C$ difficile after initial discharge and two of these children were readmitted for treatment.

In those treated with oral vancomycin the diarrhoea resolved within five days and all subsequent stool cultures were negative for $C$ difficile.

\section{Discussion}

These cases occurred in a regional nephrology unit over a three month period. The stool cultures of six other cases of haemolytic uraemic syndrome admitted to the unit during this period were negative for $C$ difficile, as were the stool cultures of the 62 children admitted with haemolytic uraemic syndrome during the previous four years. Isolates of $C$ difficile were not subtyped further, but the possibility of cross infection within the ward must be considered.

As all the affected children had $E$ coli 0157 infection identified either by microbiological and/or by serological methods, we consider that $C$ difficile is not implicated here in the pathogenesis of the haemolytic uraemic syndrome.

$C$ difficile is a common finding in the stools of normal infants and children. However the presence of $C$ difficile toxin in the stools of affected children indicates a significant pathogenicity. ${ }^{6}$ Classically diarrhoea associated with $C$ difficile follows antibiotic treatment; in particular ampicillin, amoxycillin, the cephalosporins, clindamycin, and lincomycin, but nearly all antibiotics have been implicated. ${ }^{7}$ The clinical features of symptomatic $C$ difficile infection vary from a mild self limiting diarrhoea to an acute fulminating colitis. The reported mortality is as high as $20 \% .^{5}$ The critical factor in the pathogenesis of disease associated with $C$ difficile appears to be an alteration in normal colonic microbial flora, reducing local colonisation resistance, and allowing overgrowth of the $C$ difficile. ${ }^{7}$

In haemolytic uraemic syndrome verocytotoxin is considered to be implicated in the development of diffuse endothelial damage. The subsequent microangiopathy results in ischaemia of target organs, most notably kidney, but also brain and colon. In one case of ischaemic colitis associated with haemolytic uraemic syndrome, fibrin thrombi were demonstrated in the small vessels of the resected colon. ${ }^{8}$ Such ischaemia may render the colon more susceptible to overgrowth of $C$ difficile already present in the gastrointestinal tract or acquired from the environment. This mechanism has been suggested in patients with Henoch-Schönlein purpura who develop disease associated with $C$ difficile. ${ }^{9}$ In addition uraemic patients, especially those with chronic renal failure, appear prone to diarrhoea associated with $C$ difficile. ${ }^{10}$

The diagnosis of disease associated with $C$ difficile is made by culture of the organism and identification of the toxin in the stool. Cytotoxin $B$ is the basis of most diagnostic tests, but enterotoxin A may be more important in the pathogenesis. ${ }^{7}$

Oral vancomycin is the standard treatment for disease associated with $C$ difficile. Vancomycin is minimally absorbed from the gastrointestinal tract and serum vancomycin concentrations in all of our treated patients were undetectable despite significant renal impairment. Metronidazole, orally or intravenously, is an equally effective and cheaper alternative. $^{7}$

We have demonstrated that patients with haemolytic uraemic syndrome are at increased risk of $C$ difficile infection, possibly related to increased pathogenicity of $C$ difficile already present in the patient's colon. Gastrointestinal disease associated with $C$ difficile carries a significant mortality and we would therefore advocate the judicious use of antibiotics in haemolytic uraemic syndrome and in diarrhoea associated with $C$ difficile. In addition a high index of clinical suspicion should be maintained for disease associated with $C$ difficile in those children who develop recurrent diarrhoea during the course of their haemolytic uraemic syndrome.

1 Kav J, Wise R. Causes of the haemolytic syndrome. $B M \mathcal{F}$ 1989; 289: 65-6.

2 Anonymous. Unravelling HUS [editorial]. Lancet 1987; ii 65-6.

3 Khoshoo V, Noudgil A, Vasudev AS, Bhan NK, Srivastava RN. Haemolytic uraemic syndrome associated with salmonella dysentery. Acta Paediatr Scand 1977; 88: 604-5.

4 Crabbe DCG, Brocklebank JT, Spicer RD. Gastro-intestinal complications of the haemolytic uraemic syndrome. nal complications of the haem

5 Rooney N, Variend S, Taitz LS. Haemolytic uraemic syndrome and pseudomembranous colitis. Pediatr Nephro 1988; 2: 415-8.

6 Thomson CM Jnr, Gilligan PH, Fisher MC, Long SS Clostridium difficile cytotoxin in a pediatric population. Am $\mathcal{F}$ Dis Child 1983; 137: 271-4.

7 Polson RJ. Pseudomembranous colitis associated with antibiotics. Prescriber's fournal 1992; 32: 137-41.

8 Tachen ML, Campbell JR. Colitis in children with the haemolytic uraemic syndrome. F Pediatr Surg 1977; 12: 213-9.

9 Narchi H, Beattie TJ, Taylor RG, Evans TJ, Azmy AF. Pseudo-membranous colitis in association with HenochPseudo-membranous colitis in association with

10 Leung AC, Orange G, McLay A, Henderson IS. Clostridium difficile - associated colitis in uraemic patients. Clin Nephrol 1985; 24: 242-3. 